\title{
Kelemahan Perlindungan Hukum terhadap Perempuan Dari Kekerasan Seksual di Ruang Publik
}

\author{
Wahyu Krisnanto ${ }^{1}$, Martika Dini Syaputri ${ }^{2}$ \\ ${ }^{1,2}$ Fakultas Hukum, Universitas Katolik Darma Cendika \\ Correspondence email: wahyu.krisnanto@ukdc.ac.id
}

\begin{abstract}
Abstrak. Indonesia adalah salah satu negara yang telah ikut meratifikasi Deklarasi Universal Hak Asasi Manusia dan Konvensi tentang Penghapusan Segala Bentuk Diskriminasi Terhadap Perempuan (CEDAW) dan menindaklanjuti dengan diterbitkannya berbagai perundang-undangan dan peraturan pelaksananya. Walaupun Indonesia sudah meratifikasi CEDAW dan telah menerbitkan berbagai instrumen hukum perlindungan perempuan, namun merujuk pada hasil Catatan Tahunan Komnas Perempuan tahun 2018 terjadi Kekerasan Terhadap Perempuan sebanyak 348.446 kasus, dimana 3.528 kasus terjadi di ruang publik dan 2.670 kasus kekerasan dalam bentuk kekerasan seksual. Mendasarkan pada permasalahan tersebut, dilakukan penelitian untuk mengetahui bagaimana persepsi masyarakat tehadap otonomi tubuh perempuan serta bentuk-bentuk kekerasan seksual di ruang publik yang banyak dialami perempuan. Pemahaman teoritis diharapkan dapat dijadikan landasan dalam melakukan pembaharuan hukum agar lebih efektif untuk melindungi perempuan dari kekerasan seksual di ruang publik. Penelitian ini adalah penelitian hukum dengan pendekatan ilmu sosial. Dengan penelitian yang bersifat empiris, maka metode yang dipergunakan adalah metode penelitian kualitatif dengan melakukan wawancara terstruktur terhadap perempuan dan wawancara mendalam kepada aparat kepolisian. Teknik analisa yang akan dipergunakan adalah Deskriptif Kualitatif. Dari hasil penelitian diperoleh data, bahwa kekerasan seksual disebabkan relasi kuasa yang timpang antara laki-laki dan perempuan yang mengakibatkan dipandangnya perempuan sebagai liyan. Perempuan tidak memiliki otonomi terhadap tubuhnya. Tubuh perempuan hanya dijadikan objek daya tarik seksual bagi laki-laki. Dominasi maskulinitas tidak hanya mewujud dalam bentuk kekerasan, namun juga dalam norma dan kaidah hukum. Norma dan kaidah hukum lebih bernuansa maskulin yang tidak peka keberadaan perempuan. Diperlukan adanya pembaharuan hukum yang telah ada agar menjadi menunjukkan wajah keadilan yang berkesetaraan gender.
\end{abstract}

Kata Kunci: perlindungan hokum; kekerasan seksual; perempuan, ruang public

Abstract. Indonesia is one of the countries that has ratified the Declaration on the Convention on the Elimination of all Forms of Discrimination Against Women (CEDAW) and follow up with the issuance of various laws and implementing regulations. Even though Indonesia has ratified the Convention on the Elimination of all Forms of Discrimination Against Women and has published various legal instruments for the protection of women, referring to the results of the 2018 National Commission on Violence Against Women there were 348,446 cases of Violence Against Women, of which 3,528 cases occurred in the public sphere and 2,670 cases of violence in the form of sexual violence. Based on these problems, a study was conducted to find out how people's perceptions of women's body autonomy and other forms of sexual violence in public spaces were experienced by women. Theoretical understanding is expected to be used as a basis for legal reform to be more effective in protecting women from sexual violence in the public sphere. This research is legal research with a social science approach. With empirical research, the method used is a qualitative research method by conducting structured interviews with women and in-depth interviews with police officers. The analysis technique that will be used is descriptive qualitative. From the results of the study obtained data, that sexual violence is caused by the unequal power relations between men and women resulting in the view of women as other people. Women do not have autonomy over their bodies. The female body is only used as an object of sexual attraction for men. The dominance of masculinity does not only manifest in the form of violence, but also the norms and rules of law. Legal norms and rules are more nuanced masculine that is not sensitive to the existence of women. There is a need for existing legal reforms to show the real form of gender equality.

Keywords: legal protection; sexual violence; woman, public space

\section{PENDAHULUAN}

Dalam sejarah kehidupan berbangsanya, Indonesia pernah mengalami penjajahan oleh beberapa bangsa di dunia. Karena kekayaan sumberdaya alam yang melimpah, Indonesia sebagai sebuah wilayah pernah menjadi rebutan bangsa-bangsa Eropa yang hendak menguasai wilayah Indonesia. Tidak saja bangsa Eropa (Portugis, Inggris, Belanda) yang perbah memperebutkan wilayah Indonesia pada abad $16-18$, namun bangsa Jepang dari Asia juga pernah menjajah wilayah Indonesia. Setidaknya 3,5 tahun bangsa Jepang telah menjajah wilayah Indonesia.

Dengan pengalaman kesejarahannya tersebut, bangsa Indonesia sadar bahwa penghargaan pada harkat dan martabat manusia adalah sesuatu yang perlu dijunjung tinggi. Oleh karena itu, dalam membentuk pemerintahan negaranya, bangsa Indonesia berkomitmen untuk melindungi segenap warga negara dan tumpah darahnya dengan berdasar pada kemerdekaan, perdamaian abadi dan keadilan sosial. Penghargaan 
terhadap harkat dan martabat manusia, diwujudkan dengan komitmen kebijakannya, baik eksternal maupun internal.

Secara eksternal, bangsa Indonesia berkomitmen aktif mewujudkan ketentraman dan ketertiban dunia yang berdasar pada kemerdekaan, perdamaian abadi dan keadilan sosial. Secara internal, bangsa Indonesia berkomitmen menjalankan pemerintahannya berdasar nilai Ketuhanan, Kemanusiaan yang adil dan beradab, persatuan, permusyawatan dan keadilan bagi seluruh rakyat Indonesia. Komitmen dan nilai-nilai yang dijadikan landasan bagi bangsa Indonesia dalam menjalankan pemerintahan negaranya tersebut, dinarasikan dalam Pembukaan Undang-Undang Dasar 1945 yang menjadi norma dasar kehidupan bernegara (staats fundamental norm) dan menjadi pedoman seluruh hukum positif di Indonesia baik dalam pembentukan maupun penerapannya. Walaupun tidak secara eksplisit dalam batang tubuh Undang-undang Dasar 1945 menyebutkan tentang pengakuan pada Hak Asasi Manusia, namun menilik pada narasi Pembukaan UUD 1945 menunjukkan bangsa Indonesia berkomitmen menjunjung tinggi hak asasi manusia.

Sebagai negara yang menjunjung tinggi dan melindungi Hak Asasi Manusia, Indonesia juga telah meratifikasi DUHAM. Pada tahun 1999, pemerintah Indonesia juga telah menerbitkan Undang-Undang No. 39 Tahun 1999 tentang Hak Asasi Manusia (HAM). Selain meratifikasi DUHAM, Pemerintah Indonesia juga telah meratifikasi 8 (delapan) konvensi Hak Asasi Manusia, dimana salah satunya adalah Konvensi Penghapusan Segala Bentuk Diskriminasi Terhadap Perempuan (Convention on the Elimination of All Forms of Discrimination Againts Women / CEDAW) yang dibuktikan dengan diterbitkannya UU No. 7 Tahun 1984 tentang Pengesahan Konvensi Mengenai Penghapusan Segala Bentuk Diskriminasi Terhadap Perempuan.

Dengan telah diratifikasinya CEDAW, dengan demikian pemerintah Indonesia juga telah menyetujui rekomendasi 19 tentang Kekerasan Terhadap Perempuan. Dalam rekomendasi 19 pada point 23 huruf b, dinyatakan bahwa negara peserta CEDAW wajib membuat dan menerbitkan peraturan perundangundangan yang ditujukan untuk melindungi perempuan serta mencegah kekerasan dan penganiayaan serta bentuk-bentuk lain yang berbasis gender. Banyak peraturan perundang-undangan yang telah diterbitkan oleh Pemerintah Indonesia untuk melindungi perempuan, antara lain Undang-undang No. 23 Tahun 2004 tentang Penghapusan Kekerasan Dalam Rumah Tangga; Undang-undang No. 21 Tahun 2007 tentang Pemberantasan Tindak Pidana Perdagangan Orang (TPPO) dan Undang-undang No. 44 Tahun 2008 tentang Pornografi.

Walaupun Indonesia sudah meratifikasi CEDAW dan telah menerbitkan berbagai instrumen hukum untuk perlindungan perempuan, namun merujuk pada hasil Catatan Tahunan (CATAHU) Komnas Perempuan tahun 2018 terjadi Kekerasan Terhadap Perempuan (KTP) sebanyak 348.446 kasus. Jumlah ini meningkat sekitar $34 \%$ dibanding dengan tahun 2017 yang tercatat sebanyak 259.150 kasus. Mendasarkan pada pola terjadi kasus kekerasan, kekerasan terhadap perempuan dapat dibagi ke dalam beberapa ranah yaitu: ranah personal, ruang publik serta ranah negara. Dari ketiga ranah tersebut, kasus kekerasan terbanyak terjadi di ranah personal, kedua di ruang publik dan ketiga di ranah negara. Memperhatikan terjadinya kasus kekerasan, mendasarkan pada CATAHU 2018 dan 2017, menunjukkan kekerasan fisik masih menjadi bentuk kekerasan yang paling banyak dialami oleh perempuan. Bentuk kekerasan lain yang cukup banyak adalah kekerasan seksual terhadap perempuan. Kekerasan seksual terjadi tidak saja di ranah personal, namun juga banyak terjadi di ruang publik.

Mendasarkan data Catatan Tahunan (CATAHU) Komnas Perempuan menunjukkan terjadinya peningkatan kasus kekerasan terhadap perempuan di ranah publik sekitar 14\% sejak tahun 2017 hingga 2018. Pada tahun 2017 lalu, terdapat 3.092 kasus kekerasan terhadap perempuan di ranah publik. Sedangkan pada tahun 2018 terjadi 3.528 kasus kekerasan terhadap perempuan di ranah publik. Dari kasus terjadinya kekerasan terhadap perempuan di ranah publik tersebut, menunjukkan bahwa kasus kekerasan dalam bentuk pelecehan seksual dan pencabulan menempati urutan teratas terjadnya kasus. Berdasar CATAHU tahun 2017, kasus pelecehan seksual dan pencabulan di ranah publik terjadi sebanyak 2.290 (74\%) kasus ${ }^{1}$. Sedangkan pada CATAHU 2018 tercatat kasus pelecehan seksual dan pencabulan di ranah publik terjadi sebanyak $2.681(76 \%)$ kasus $^{2}$. Hal yang perlu dicatat dan diperhatikan dari kenaikan angka kejadian kasus kekerasan seksual terhadap perempuan di ruang publik tersebut adalah data merupakan hasil pengumpulan data dari berbagai sumber antara lain dari (1) lembaga layanan mitra Komnas Perempuan; (2) Unit Pelayanan dan Rujukan (UPR) Komnas Perempuan serta dari (3) Divisi Pemantauan Komnas Perempuan yang mengelola pengaduan dari masyarakat. Dalam faktanya angka kejadian tersebut tentunya lebih tinggi dari data yang terlaporkan. Bahkan masih sangat sedikit kasus kekerasan seksual terhadap perempuan di ranah komunal/publik yang terselesaikan melalui proses hukum. Penyelesaian kasus kekerasan seksual terhadap perempuan melalui proses hukum masih banyak didominasi di ranah personal.

Sedikitnya kasus kekerasan seksual di ranah komunal/publik melalui proses hukum, meninggalkan

1 Catatan Tahunan (CATAHU) Komisi Nasional Perempuan, 2017, Hal. 2

2 Catatan Tahunan (CATAHU) Komisi Nasional Perempuan, 2018, Hal. 1 
sebuah pertanyaan tersendiri. Apa faktor penyebab terjadinya kekerasan seksual terhadap perempuan di ranah komunal/publik ?, bagaimana dampak yang ditimbulkan akibat adanya kekerasan seksual di ranah komunal/publik ?. apakah belum tertanganinya kasus kekerasan seksual terhadap perempuan di ranah komunal/publik melalui proses hukum disebabkan karena tidak adanya pengaturan hukum, ataukah disebabkan oleh faktor-faktor lain di luar aspek yuridis formal ?. Dengan mendasarkan pertanyaan utama tersebut, dalam artikel ini akan diuraikan hasil penelitian yang menganalisis faktor-faktor penyebab tidak tertanganinya kasus kekerasan seksual terhadap perempuan di ranah komunal/publik melalui proses hukum serta dampak yang dialami oleh korban akibat kekerasan seksual tersebut.

Mendiskusikan kasus kekerasan seksual terhadap perempuan dengan segala penyelesaiannya kasusnya, tidak hanya mendiskusikan dari aspek yuridis semata. Namun ada aspek sosiologis dan psikologis yang juga perlu didiskusikan secara mendalam. Pembahasan aspek sosiologis diperlukan untuk menganalisis motif terjadinya kasus kekerasan seksual terhadap perempuan dan dampak yang dialami oleh korban akibat kekerasan seksual yang dialaminya. Analisis aspek Psikologis diperlukan untuk mengetahui beban psikologis yang dialami oleh korban pasca terjadinya kekerasan seksual. Sedangkan analisis dari aspek Yuridis diperlukan untuk mengetahui kelemahan pengaturan Kitab Undangundang Hukum Pidana (KUHP) maupun Kitab Undangundang Hukum Acara Pidana (KUHAP) dalam melakukan proses hukum terhadap pelaku kekerasan seksual di ranah komunal/publik.

Dengan dilakukannya analisis lintas aspek tersebut, diperoleh pemahaman secara komprehensif kendala penanganan kasus kekerasan seksual terhadap perempuan di ranah komunal/publik melalui proses hukum. Pemahaman secara komprehensif tersebut juga diharapkan dapat memberikan rekomendasi pembaharuan hukum terhadap perlindungan perempuan, khususnya dari tindak pidana kekerasan seksual di ruang publik.

\section{METODE}

Artikel ini adalah hasil sebuah penelitian yang dilakukan di Kota Surabaya, dimana penelitian ini bersifat kualitatif dan dimaksudkan untuk mengetahui faktor penyebab tidak maksimalnya penyelesaian hukum kasus kekerasan seksual terhadap perempuan di ruang publik. Dengan mengidentifikasi faktor sosiologis, psikologis sekaligus yuridis, maka diperlukan pendekatan ilmu sosial dalam telaah dalam bidang hukum. Dengan menggabungkan disiplin ilmu sosial dengan ilmu hukum, maka secara konseptual penelitian dikategorikan sebagai penelitian sosio legal. Dengan penelitian sosial legal ini, penelitian dilakukan dengan pendekatan interdisipliner yang menggunakan konsep dan teori dari berbagai ilmu yang dikombinasikan dan digabungkan untuk mengkaji sebuah fenomena hukum (Wignjosoebroto; 2007).

Untuk mengidentifikasi faktor-faktor penyebab belum maksimalnya proses hukum terhadap kasus kekerasan seksual terhadap perempuan di ranah komunal/publik, dilakukan wawancara terhadap beberapa kelompok responden yang meliputi: kelompok responden perempuan dan kelompok responden penegak hukum (Polri). Kelompok responden perempuan dipilih untuk mengetahui pengalaman mereka mendapat perlakuan kekerasan seksual di ranah komunal/publik serta upaya proses hukum yang pernah mereka lakukan ketika mendapat kekerasan seksual di ranah komunal/publik. Sedangkan alasan dilakukannya pemilihan kelompok responden penegak hukum (Polri) dimaksudkan untuk mengetahui permasalahan pengaturan hukum, khususnya pada tahap penyidikan dan penetapan dakwaan kepada tersangka pelaku kekerasan. Tahap penyidikan dan penetapan dakwaan kepada pelaku kekerasan yang dilakukan oleh pihak kepolisian pada dasarnya adalah pintu masuk dilakukanya pemrosesan hukum. Oleh karena itu diperlukan informasi yang akurat permasalahan pengaturan hukum yang dihadapi oleh aparat kepolisian untuk menetapkan dakwaan kepada pelaku kekerasan seksual di ruang publik.

Sebagai sebuah penelitian yang bersifat deskriptif, metode penelitian yang dipergunakan adalah campuran/mix method (kualitatif dan kuantitatif). Data secara kualitatif diperoleh melalui wawancara mendalam (in depth interview) sedangkan data yang bersifat kuantitatif diperoleh melalui wawancara secara terstruktur (kuesioner). Hasil wawancara terstruktur akan diperoleh data kuantitatif yang bersifat deskriptif semata tanpa melakukan pengukuran antar variabel. Wawancara terstruktur dilakukan terhadap kelompok responden perempuan. Sedangkan wawancara mendalam dilakukan terhadap aparatur penegak hukum (Polri).

Mengingat metode penelitian mempergunakan metode campuran (mix method), maka teknik pengambilan sampel responden juga akan bersifat campuran. Untuk kelompok responden perempuan, teknik pengambilan sampel responden yang dipergunakan adalah Sampel Acak Kebetulan (Accidental Sampling). Dengan teknik ini, maka peneliti mewawancarai setiap perempuan yang dapat ditemui di area umum dengan kriteria minimal berusia remaja (di atas 12 tahun). Jumlah responden untuk kelompok perempuan sebanyak 100 orang. Sedangkan untuk responden dari kelompok aparat penegak hukum dilakukan dengan teknik purposive sampling. Terdapat 5 orang aparatur kepolisian yang diwawancara. Seluruh data hasil wawancara ini selanjutkan akan dianalisa menggunakan teknik Deskriptif Kualitatif. 


\section{HASIL DAN PEMBAHASAN}

Sebelum membahas tentang berbagai hal terkait hasil pengumpulan dan analisa data penelitian tentang kekerasan seksual terhadap perempuan di ruang publik, ada baiknya dimulai dengan memahami pengertian kekerasan seksual dan ruang publik. Penyepakatan atas konsepsi atau definisi tentang kekerasan seksual dan ruang publik diperlukan agar tidak terjadi beda pemahaman atas kedua frasa tersebut. Pada bagian selanjutnya, akan diuraikan tentang pola terjadinya kekerasan seksual terhadap perempuan di ruang publik, kekosongan hukum serta permasalahan birokrasi di institusi pemerintah dan kepolisian dalam penanganan kasus kekerasan seksual terhadap perempuan di ruang publik.

\section{Pengertian Kekerasan Seksual}

Mendefinisikan kekerasan (violence) sangat bergantung pada konteks budaya dan masyarakatnya (Levi, 1994). Pada satu budaya masyarakat tertentu suatu tindakan terhadap seseorang dapat dianggap sebagai kekerasan. Namun pada masyarakat lain tindakan yang sama yang dilakukan seseorang kepada orang lain, mungkin tidak dikategorikan sebagai tindakan kekerasan. Sebagai contoh pada budaya masyarakat Jawa, tindakan seorang ibu yang menjewer kuping anaknya karena tidak patuh padanya dianggap bukan tindakan kekerasan. Namun tindakan sama yang dilakukan oleh seorang ibu pada anaknya pada budaya masyarakat lain, dapat dikategorikan sebagai tindakan kekerasan.

Pada awalnya kekerasan didefinisikan sebagai kekerasan yang bersifat fisik. Hal ini seperti pendapat Neil Alan Weiner, dkk (1990) yang mengatakan bahwa tindakan dikategorikan sebagai kekerasan adalah tindakan ancaman, upaya, atau penggunaan kekuatan fisik oleh satu atau lebih banyak orang yang mengakibatkan luka fisik atau non fisik kepada satu atau lebih orang lain ("the threat, attempt, or use of physical force by one or more persons that results in physical or non physical harm to one or more other persons").

Definisi di atas masih mengarah pada kekerasan yang bersifat fisik, walaupun dampak yang dihasilkan dari kekerasan tersebut dapat berupa luka fisik maupun non fisik. Definisi kekerasan di atas belum mampu menjelaskan jenis kekerasan yang terkait dengan status gender seseorang, Kekerasan berdasar gender ini merujuk pada kekerasan yang dialami oleh perempuan. Kekerasan yang dialami oleh perempuan ini tidak saja terkait dengan fisik, namun juga kekerasan yang bersifat non fisik (psikologis).

Pengertian kekerasan berdasar gender ini kemudian diadopsi oleh PBB saat Deklarasi Penghapusan Kekerasan Terhadap Perempuan. Pada Pasal 1 dalam Deklarasi tersebut dinarasikan bahwa yang dimaksud dengan Kekerasan Terhadap Perempuan adalah setiap tindakan kekerasan berbasis gender yang berakibat atau mungkin mengakibatkan kesengsaraan/penderitaan secara fisik, seksual atau psikologis terhadap perempuan, termasuk didalamnya adalah ancaman, pemaksaan atau perampasan kebebasan sewenang-wenang, baik yang terjadi di depan umum atau dalam kehidupan pribadi.

Dari penjelasan Pasal 1 Deklarasi Penghapusan Kekerasan Terhadap Perempuan, semakin jelas bahwa pengertian kekerasan menjadi lebih luas baik jenis, tempat terjadinya kekerasan serta akibat yang dihasilkan. Dari jenisnya, kekerasan terhadap perempuan dapat bersifat fisik dan non fisik. Kekerasan non fisik ini dibagi menjadi 2 jenis, yaitu kekerasan verbal (berupa kata-kata atau sikap mempermalukan di depan umum) maupun kekerasan psikologis (seperti memandang penuh nafsu, sinis, memandang untuk mengancam, dll). Ditinjau dari tempat terjadinya kekerasan, dapat dibagi menjadi 3 ranah, yaitu ranah privat (kekerasan terjadi dalam keluarga), ranah komunitas/publik (terjadinya kekerasan berada di tempat umum) dan di ranah negara (terjadinya kekerasan berada dalam konteks hubungan negara dengan warganya). Sedangkan ditinjau dari akibatnya, kekerasan dapat berbentuk luka-luka secara fisik maupun psikologis yang menimbulkan trauma bagi korban kekerasan.

Dalam pengertian kekerasan yang termuat dalam Deklarasi Penghapusan Kekerasan Terhadap Perempuan telah disinggung adanya kekerasan seksual. Kekerasan seksual tidak selalu diartikan sebagai tindakan pemaksaan secara fisik (perkosaan) tetapi juga bujuk rayu untuk melakukan hubungan seksual tanpa diingini oleh korban. Komentar yang terkait dengan seksual dan pandangan mata penuh nafsu pada seseorang tanpa diinginkan oleh korban, dapat juga dikategorikan sebagai kekerasan seksual. Pengertian ini seperti yang ditegaskan oleh Lembaga Kesehatan Dunia (WHO). Lembaga Kesehatan Dunia (WHO) mendefinisikan kekerasan seksual sebagai upaya dan/atau tindakan seksual yang dipaksakan (perkosaan), komentar yang tidak diinginkan terkait dengan seksual, kontak seksual dengan paksaan atau ancaman oleh setiap orang tanpa memandang hubungan mereka dengan korban dalam pengaturan apapun dan tidak terbatas pada rumah maupun pekerjaan (World Health Organization, 2016; 149).

Definisi tentang kekerasan seksual tersebut dijabarkan oleh Komisi Nasional Perlindungan Perempuan dalam 15 bentuk kekerasan yang dikategorikan sebagai kekerasan seksual. Pengkategoian kekerasan seksual ini didasarkan pada hasil pemantauan Komnas Perlindungan Perempuan selama 15 tahun sejak 1998 hingga 2013. Kelimabelas jenis kekerasan yang dikategorikan kekerasan seksual adalah : (1) Perkosaan; (2) Pelecehan seksual; (3) Eksploitasi seksual; (4) Penyiksaan seksual; (5) Perbudakan seksual; (6) 
Intimidasi/serangan bernuansa seksual termasuk ancaman atau percobaan perkosaan; (7) Prostitusi paksa; (8) Pemaksaan kehamilan; (9) pemaksaan aborsi; (10) pemaksaan perkawinan; (11) perdagangan perempuan untuk tujuan seksual; (12) Kontrol seksual termasuk pemaksaan busana dan kriminalisasi perempuan lewat aturan diskriminatif beralasan moralitas dan agama; (13) Penghukuman tidak manusiawi dan bernuansa seksual; (14) Praktik tradisi bernuansa seksual yang membahayakan atau mendiskriminasikan perempuan dan (15) Pemaksaan pemakaian kontrasepsi/sterilisasi (Komnas Perempuan, 2009).

\section{Pengertian Ruang Publik}

Ruang Publik memiliki banyak definisi. Ruang public bisa diartikan sebagai sebuah ruang yang bersifat fisik (spasial), namun juga dapat diartikan sebagai ruang yang bersifat transedensi yang dapat diisi oleh warga masyarakat untuk mengungkapkan aspirasi dan opininya. Ruang Publik yang dimaksudkan sebagai public space, terkadang dipadankan dengan public sphere. Dengan banyaknya pengertian ruang public dan untuk menyamakan pemahaman tentang ruang publik, pada bab ini akan diuraikan pengertian ruang public yang mana yang akan dipergunakan dalam penelitian ini.

Sebelum membahas tentang pengertian ruang publik, ada baiknya terlebih dahulu memahami apa yang dimaksud dengan publik. Kata "publik" (public) bukan sebuah kata yang berasal dari Bahasa Indonesia. Kata publik adalah serapan kata yang sebenarnya berasal dari Bahasa Yunani. Publik selalu dilawankan artinya dengan privat yang berarti memiliki intimitas lebih pribadi seperti keluarga, anggota, kewargaan, dan lain sebagainya.

Konsep public dalam sejarah Yunani, munculnya bersamaan dengan polis (negara kota). Sebelum mengenal adanya Polis, masyarakat Yunani hanya mengenal kehidupan keluarga yang bersifat natural/alamiah. Dalam perkembangannya, masyarakat Yunani berkelompok membentuk sebuah organisasi politik dalam sebuah satuan wilayah tertentu yang kemudian dikenal dengan istilah Polis. Kehidupan bersama dalam sebuah Polis tersebut, memberikan kehidupan "kedua" bagi masyarakat Yunani selain hidup privat dalam keluarga. Kehidupan bersama dalam organisasi politik inilah yang kemudian dikenal menimbulkan distingsi "public" dan "privat". (Wibowo; 2010).

Dalam konteks pemahaman publik dalam bahasa Indonesia, penggunaan kata publik sebenarnya bukan berasal dari bahasa Yunani, namun berasal dari bahasa Latin yang sering dipergunakan dalam bahasa Romawi Kuno yang berarti Publicus. Dalam bahasa Romawi, Publicus memiliki dua arti. Pertama berarti milik rakyat sebagai satuan politis atau milik negara dan yang Kedua adalah sesuai dengan rakyat sebagai seluruh penduduk atau "umum" (Hardiman; 2010). Dengan memperhatikan pada perbedaan terminologi tentang Publik, penulis dalam penelitiannya mempergunakan Publik dalam pemahaman bahasa Latin yang berarti umum. Dengan pengertian ini, maka Publik yang dimaksudkan dalam penelitian ini adalah kondisi dimana rakyat sebagai sebuah penduduk dapat mempergunakan bersama-sama.

Dimilikinya berbagai pengertian tentang Publik juga terjadi ketika frasa itu digabungkan dengan frasa "Ruang". Terjadi keberagaman definisi tentang Ruang Publik. Keberagaman definisi tersebut bergantung pada perspektifnya, baik dari perspektif geografi dan arsitektur, perspektif filsafat, perspektif ekonomi, perspektif ilmu kebijakan, perspektif budaya dan perspektif sosiologis. Dalam penelitian ini, akan dipergunakan perspektif geografi dan arsitektur.

Henri Lefebvre dalam Priyono (B. Herry Priyono, 2010) mengatakan ruang publik lebih merujuk pada jaringan keterlibatan dan ruang sosial tertentu yang menyangga kerjasama dan koordinasi civitas, terutama dalam interaksi antara kota besar dan ekonomi lokal. Senada dengan pendapat Lefebvre, menurut Caroline yang dimaksud dengan ruang publik secara normatif adalah sebagai suatu wilayah kehidupan sosial dimana semua orang dapat berkumpul bersama dan secara bebas mengidentifikasi dan mendiskusikan berbagai bentuk permasalahan sosial. Dengan demikian ruang publik dipahami sebagai suatu produk arsitektur yang direncanakan dan dirancanguntuk mewadahi kegiatan individu maupun berkelompok dalam relasi sosialnya (Karya Widyawati, 2011).

\section{Pola dan Bentuk Terjadinya Kekerasan Seksual di Ruang Publik}

Untuk mengidentifikasi pola terjadinya kekerasan seksual terhadap perempuan di ruang publik dilakukan wawancara terhadap 100 orang responden perempuan dengan distribusi usia responden sebagai berikut :

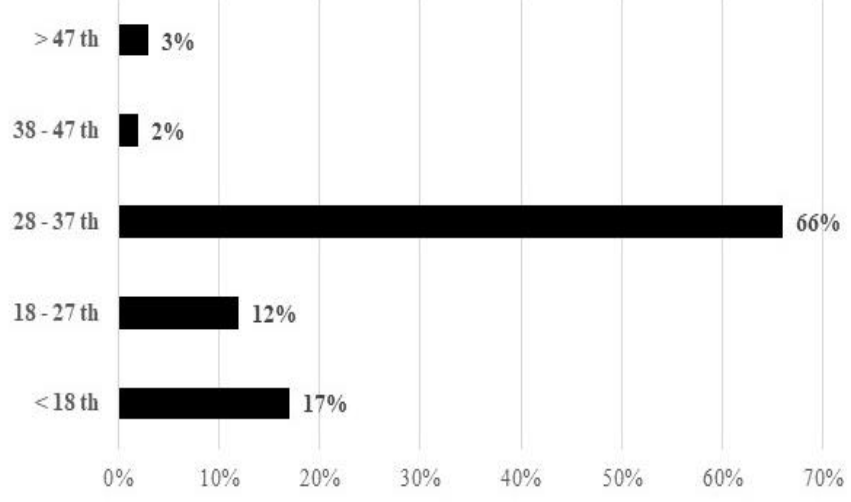

Gambar 1. Distribusi Usia Responden Perempuan

Dari 100 orang responden perempuan diketahui $63 \%$ orang responden perempuan menjawab pernah mengalami dan $37 \%$ orang responden menjawab tidak 
pernah mengalami kekerasan seksual di ruang publik. Dari $63 \%$ responden perempuan yang menjawab pernah mendapatkan perlakuan kekerasan seksual, terdistribusi pada semua usia. Walaupun sebagian besar usia kelompok perempuan yang mendapat perlakuan kekerasan seksual di ruang publik adalah usia remaja dan dewasa, namun kekerasan seksual juga dialami oleh perempuan pada usia anak-anak dan orang tua $(>47$ tahun).

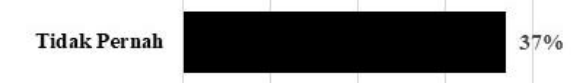

Pernah Mengalami

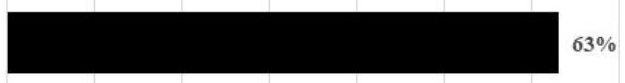

$\begin{array}{llllllll}0 \% & 10 \% & 20 \% & 30 \% & 40 \% & 50 \% & 60 \% & 70 \%\end{array}$

Gambar 2. Pengalaman Mendapat Kekerasan Seksual di Ruang Publik

Kekerasan seksual di ruang publik, terjadi tidak saja di tempat-tempat umum (seperti halte bus/trotoar jalan/terminal/stasiun/mall/dsb) namun juga di transportasi umum seperti kereta api komuter, bus atau angkutan perkotaan (bus kota/angkot). Beberapa orang responden bahkan mengaku pernah mengalami perlakuan kekerasan seksual tempat yang selama ini dipersepsikan secara sosial sebagai tempat dimana moralitas dijunjung tinggi seperti tempat ibadah dan sekolah/kampus. Perlakuan kekerasan seksual di tempat ibadah, biasanya dalam bentuk tatapan mata penuh nafsu. Sedangkan perlakuan kekerasan seksual di sekolah/kampus, biasa dilakukan oleh teman sebaya, karyawan sekolah, guru/dosen. Biasanya kekerasan seksual di sekolah/kampus dalam bentuk obrolan yang menjurus pada ajakan kencan, ucapan canda yang mengarah pada sensualitas tubuh, siulan dan colekan pada tubuh perempuan. Seorang responden perempuan bahkan mengaku pernah mendapat kekerasan seksual dari seorang laki-laki di sekolah/kampus dalam bentuk menunjukkan alat kelaminnya (exhibitionist).

Dari jawaban responden tersebut, menunjukkan tempat umum dan transportasi umum yang terdapat banyak orang, bukan berarti menjadikan tempat tersebut aman bagi perempuan. Justru dengan banyak orang, dipergunakan oleh pelaku untuk mengelabuhi perilakunya dalam melakukan kekerasan seksual terhadap perempuan. Pelaku kekerasan leluasa dalam menjalankan aksinya, karena sebagian besar orang-orang yang berada di sekitarnya menganggap bahwa tindakan yang dilakukan oleh pelaku tidak dikategorikan sebagai kekerasan (kecuali perilaku exhibitionist).

\section{Respon Dan Dampak Yang Dialami Oleh Korban Kekerasan Seksual Di Ruang Publik}

Kekerasan seksual di ruang publik jarang sekali yang bersifat fisik hingga melukai korbannya (melakukan perkosaan/ruda paksa).Tanpa adanya kekerasan fisik, menjadikan masyarakat menganggap kekerasan seksual hanya sebagai sebuah candaan semata. Berbeda dengan anggapan masyarakat, pengalaman kekerasan seksual sebenarnya memberikan pengalaman traumatik bagi korban. Hal ini dapat diketahui dari jawaban 63 responden perempuan yang pernah mengalami kekerasan seksual di ruang publik. Dari hasil wawancara terhadap 63 responden tersebut, diketahui bahwa $79 \%$ responden menjawab mengalami trauma dan $21 \%$ responden menjawab tidak mengalami trauma.

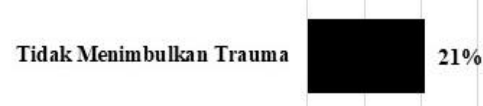

Ya, menimbulkan trauma

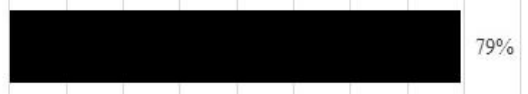

$\begin{array}{llllllllll}0 \% & 10 \% & 20 \% & 30 \% & 40 \% & 50 \% & 60 \% & 70 \% & 80 \% & 90 \%\end{array}$

Gambar 3. Kekerasan Menimbulkan Pengalaman Traumatik Bagi Korban

Pengalaman traumatik kekerasan seksual ini direspon dalam berbagai macam sikap oleh korban. Sebagian responden perempuan merespon pengalaman perlakuan kekerasan seksualnya dengan sikap rasa takut bepergian sendiri. Beberapa responden perempuan korban kekerasan seksual bahkan menyalahkan dirinya sendiri dengan menganggap dirinya berperilaku atau berpakaian tidak pantas di depan umum. Respon perempuan korban kekerasan seksual dengan cara mereviktimisasi diri mereka dengan membatasi kebebasan otonomi tubuhnya. Kondisi korban kekerasan seksual yang melakukan reviktimisasi dirinya ini juga ditemukan dalam data hasil penelitian yang dilakukan oleh Abby Gina dan Gadis Arivia (Arivia, 2016), Dalam penelitiannya tentang kekerasan seksual dan simbolis yang dilakukan di Jakarta, Gina dan Arivia juga menemukan kondisi dimana perempuan korban kekerasan seksual menunjukkan sikap submisif terhadap pengalaman kekerasan seksual mereka dan mereviktimisasi dirinya dengan cara merelakan otonomi tubuh direduksi oleh keadaan.

Sikap mereviktimisasi diri korban ini juga terlihat dari jawaban mereka yang tidak melaporkan pengalaman mendapatkan kekerasan seksual kepada pihak aparat kepolisian. Dari hasil wawancara terhadap 63\% responden korban kekerasan seksual di ruang publik, diketahui hampir seluruh korban (94\%) tidak 
melaporkan kekerasan seksual yang dialaminya. Terdapat beberapa alasan yang menyebabkan korban tidak melaporkan kejadian kekerasan seksual yang dialami kepada polisi. Dari jawaban responden, diketahui alasan terbanyak karena adanya perasaan malu untuk melaporkan $(22 \%)$ dan malas berurusan dengan pihak kepolisian karena anggapan proses hukum kekerasan seksual di ruang publik akan menyita waktu dan sulit pembuktiannya. Selain daripada itu, para korban enggan untuk melapor perlakuan kekerasan seksual yang dialami karena beranggapan kekerasan tersebut tidak menimbulkan luka-luka secara fisik.
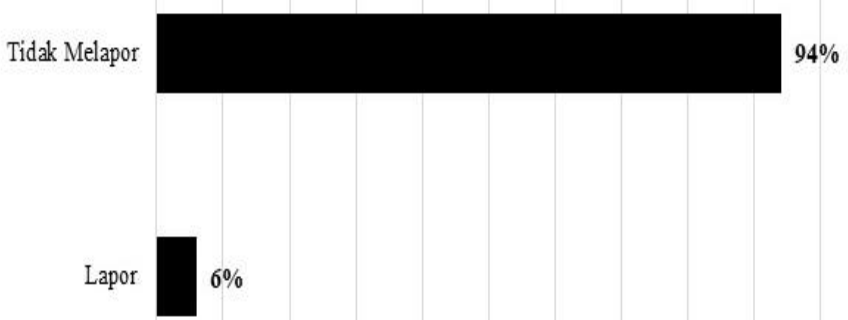

$\begin{array}{lllllllllll}0 \% & 10 \% & 20 \% & 30 \% & 40 \% & 50 \% & 60 \% & 70 \% & 80 \% & 90 \% & 100 \%\end{array}$

Gambar 4. Korban Melaporkan Kekerasan Seksual Yang Dialami kepada Pihak Berwajib

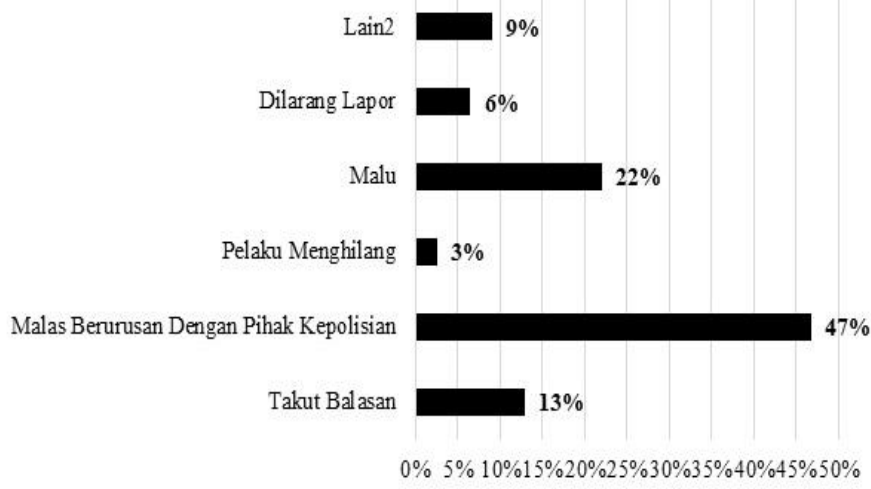

Gambar 5. Alasan Korban Tidak Melapor Kepada Pihak Kepolisian

Tidak melapornya korban kepada pihak kepolisian, sebenarnya merupakan sikap permisif dalam menghadapi kekerasan yang dialami. Kondisi ini tidak terlepas dari tidak dimilikinya kesadaran kritis dari korban. Korban tidak menyadari bahwa tindakan kekerasan seksual yang dialami sebenarnya telah melecehkan harkat dan martabatnya sebagai perempuan, dimana ia sebagai perempuan dijadikan objek seksual bagi pria. Tidak dimilikinya kesadaran kritis ini tentunya tidak dapat dipisahkan dari konstruksi sosial posisi perempuan dibanding laki-laki.

Memperhatikan data di atas, menunjukkan perempuan pada kasus kekerasan seksual di ruang publik pada posisi yang sangat lemah. Korban kekerasan seksual menganggap kekerasan seksual bukan sebagai tindakan pelecehan terhadap harkat dan martabatnya sebagai manusia yang memiliki otonomi terhadap tubuhnya. Mereka lebih memilih untuk diam, membiarkan pengalaman kekerasan seksual yang dialami sebagai pengalaman buruk dan menjadi ia bergantung pada orang lain untuk menemaninya selama beraktifitas di tempat umum atau transportasi umum. Kekerasan seksual yang dialami dianggap sebagai aib yang perlu ditutupi dan orang lain (termasuk pihak kepolisian) tidak perlu tahu. Sebagian besar responden menganggap perilaku laki-laki yang berbuat kekerasan seksual terhadap perempuan sebagai perbuatan yang lumrah. Mereka menganggap kodrat laki-laki untuk tertarik secara seksual terhadap perempuan dan mencandainya walaupun candaan itu mengarah pada pelecehan seksual.

Sikap permisif perempuan korban kekerasan seksual di ruang publik tidak dapat dipisahkan dari bagaimana masyarakat mengkonstruksikan perempuan dalam relasinya dengan laki-laki. Mempergunakan pemikiran Bourdieu (1995) dalam bukunya "Language and Symbolic Power" dijelakan bahwa relasi laki-laki dan perempuan tidak dapat dipisahkan dari pemahaman tentang kelas sosial dalam stuktur sosial yang kemudian ditanamkan melalui pembudayaan dalam kehidupan sosial yang bersifat simbolik. Dalam kehidupan masyarakat terdapat kelas sosial tertentu yang akan mendominasi dan menguasai kelas sosial lainnya. Untuk menunjukkan kuasa pada kelas sosial tertentu diperlukan adanya kekerasan dan tindakan diskriminatif yang bersifat simbolik. Dominasi, Kuasa dan Kekerasan yang bersifat simbolik tersebut diinternalisasikan dalam struktur sosial masyarakat melalui instrument pengetahuan dan ekspresi sosial yang tidak disadari oleh masyarakat.

Relasi kuasa dan seksualitas antara laki-laki dan perempuan ini dijelaskan lebih rinci oleh Foucault (2008) dalam bukunya "La Volonté de Savoir (Histoire de la Sexualité)". Menurut Foucault, kekuasaan bukan lagi kepemilikan namun menjadi sebuah strategi yang diterima tanpa paksaan dan menyebar ke semua wilayah kehidupan sosial. Kekuasaan tidak lagi bersifat represif dan destruktif, namun mewujud dalam konstruksi sosial tentang norma dan aturan-aturan sosial (regulation) yang direproduksi menjadi pengetahuan sesuai konstruksi pemegang kekuasaan. Dengan pengetahuan, pemegang kekuasaan melakukan pengawasan (kontrol) terhadap pihak yang dikuasai tanpa mereka menyadari dibawah kontrol penguasa. Agar kekuasaan benar-benar mampu menguasai pihak yang dikuasai secara efektif tanpa ada upaya pemaksaan, maka perlu dilakukan pelembagaan melalui institusi keagamaan, budaya dan negara. Lebih lanjut Foucault mengatakan dominasi kekuasaan juga diwujudkan dalam disiplin yang menyentuh tubuh pihak yang dikuasai melalui pengaturan waktu beraktivitas, 
sikap tubuh yang ideal, serta sikap tubuh dalam berelasi dengan sesama (Foucault, 1980).

Mempergunakan pemikiran Bourdieu dan Foucault, dalam konstruksi sosialnya laki-laki ditempatkan sebagai kelas sosial pertama dan perempuaan sebagai kelas sosial kedua. Kekerasan seksual dialami oleh perempuan adalah ekspresi simbolik kuasa laki-laki terhadap perempuan. Perempuan tidak ditempatkan sebagai subjek, namun menjadi obyek seksual yang dapat dikuasi oleh laki-laki. Dengan system pengetahuan dan melalui pembudayaan yang bersifat simbolik, kekerasan tidak lagi dirasa sebagai tindakan semena-mena namun dianggap sebagai sebuah perilaku kodrati. Reviktimisasi diri korban kekerasan seksual adalah kuasa dan dominasi laki-laki melalui sistem pengetahuan yang menjadikan korban memandang terjadinya kekerasan bukan sebagai tindakan semena-mena dari pelaku (laki-laki) terhadap dirinya, namun sebagai kekeliruan diri untuk berperilaku "normal" dalam beraktivitas di tempat umum atau transportasi umum.

Ketidaksadaran perempuan berada dalam dominasi dan kuasa laki-laki juga dijelaskan oleh Simone de Beauvoir (Beauvoir, 1989; Arivia, 2003) dalam bukunya "Second Sex". Dalam tesisnya, Beauvoir mengatakan bahwa masyarakat mengkonstruksikan perempuan karena kondisi biologinya sebagai mahluk yang lemah sehingga perlu untuk dilindungi. Perlindungan didapat dari mahluk yang memiliki kekuatan tenaga, yaitu laki-laki. Tanpa kehadiran lakilaki, perempuan menjadi mahluk yang lemah. Karena perlindungan dari laki-laki tersebut, maka semua kehidupan perempuan didefinisikan dan dikonstruksikan berdasar pemikiran laki-laki dan bukan sebaliknya. Tubuh perempuan ada bukan "untuk dirinya" atau "pada dirinya", namun tubuh perempuan ada "untuk orang lain" yang mampu memberikan perlindungan terhadap dirinya. Dengan konstruksi ini, menempatkan perempuan sebagai "liyan" (the others) dari dirinya.

\section{Permasalahan Substansi Hukum Dalam Perlindungan Perempuan dari Kekerasan Seksual di Ranah Komunal/Publik}

Mendiskusikan masalah kekerasan seksual terhadap perempuan tidak hanya mendiskusikan tentang bagaimana masyarakat mengkonstruksikan relasi lakilaki dan perempuan sebagai akar penyebab terjadinya kekerasan seksual, namun juga perlu mendiskusikan faktor-faktor yuridis formal yang juga berkontribusi mengakibatkan perlindungan terhadap perempuan dari kekerasan seksual tidak berfungsi secara maksimal.

Dalam sistem hukum, terdapat 3 (tiga) komponen yang saling melengkapi agar sebuah sistem dapat berfungsi secara maksimal. Lawrence W. Friedman (1984) menjelaskan terdapat tiga komponen yang mempengaruhi sistem hukum, yaitu kultur hukum, substansi hukum dan struktur hukum. Kultur hukum pada dasarnya adalah perilaku sosial masyarakat sebagai tanggapan terhadap hukum. Tanggapan masyarakat terhadap hukum tentunya sangat dipengaruhi oleh sistem nilai, norma dan paradigma masyarakat. Pada pembahasan sebelumnya, telah diuraikan tanggapan masyarakat, utamanya kelompok perempuan, terhadap kekerasan seksual yang dialaminya. Mereka sangat permisif pada kekerasan seksual di ranah komunal/publik yang mereka alami. Sikap permisif ini tentunya tidak dapat dipisahkan dari nilai atau normal yang mereka anut sebagai hasil konstruksi sosial.

Substansi hukum adalah pengaturan-pengaturan baik secara tertulis maupun tidak tertulis yang dijadikan pedoman dalam penyelesaian sebuah pelanggaran hukum. Dalam substansi hukum sendiri terdapat komponen hukum materiil dan formil. Komponen hukum materiil berupa peraturan yang mengatur tentang perbuatan yang dikategorikan sebagai kejahatan atau pelanggaran, unsur deliknya serta sanksi yang diberikan. Komponen hukum formil adalah peraturan yang dipergunakan untuk mengatur cara penegasan hukum materiil, mulai proses penyelidikan, penyidikan, pemeriksaan hingga penjatuhan sanksi bagi pelanggar hukum. Dengan kata lain hukum formil ini pada dasarnya adalah peraturan yang dipergunakan mengatur penegakan hukum formil (hukum acara). Mengingat kekerasan seksual terhadap perempuan dikategorikan sebagai perbuatan pelanggaran pidana, maka hukum formil yang dipergunakan adalah Kitab Undang-undang Hukum Acara Pidana (KUHAP).

Dalam bagian ini akan didiskusikan tentang apakah substansi hukum dalam sistem hukum di Indonesia benar-benar telah mampu memberikan perlindungan terhadap perempuan dari kekerasan seksual di ruang publik. Namun sebelum itu, baik kiranya jika terlebih dahulu memahami pengertian tentang kekerasan seksual. Pemahaman ini untuk mengetahui apakah perbuatan yang sebenarnya dikategorikan sebagai perbuatan kekerasan seksual, telah diatur dalam hukum materiil di Indonesia sebagai sebuah pelanggaran. Jika perbuatan yang sebenarnya dikategorikan sebagai kekerasan seksual namun berbeda dengan definisi kekerasan seksual sebagaimana diatur dalam hukum materiil, maka sulit kiranya untuk memberikan sanksi pidana pada pelaku.

Mendasarkan pada definisi tentang kekerasan seksual yang dibuat oleh World Health Organization (WHO) dan memperhatikan pada fakta sosial, menunjukkan bahwa kekerasan seksual di ruang publik lebih banyak bersifat verbal seperti tatapan mata penuh nafsu, komentar, atau gurauan yang mengarah pada halhal seksual serta obrolan yang menjurus pada ajakan untuk berkencan. Fakta sosial tentang bentuk kekerasan seksual terhadap perempuan di ruang publik ini, jika disandingkan dengan pengertian tentang kekerasan 
seksual sebagaimana yang telah diatur dalam hukum materiil yang berlaku di Indonesia, menjadi tidak tepat.

Kitab Undang-undang Hukum Pidana (KUHP) sebagai hukum materiil yang mengatur tentang pelanggaran pidana sebenarnya tidak mengenal istilah kekerasan seksual ataupun pelecehan seksual. Dalam KUHP hanya mengenal istilah perbuatan cabul yang diatur pada Bab XIV tentang Kejahatan Terhadap Kesusilaan, khususnya pada Pasal 285 hingga Pasal 296. Pada pasal-pasal tersebut diatur tentang perbuatan apa saja yang dikategorikan sebagai pelanggaran terhadap kesusilaan serta sanksi hukuman terhadap pelanggar. Perbuatan cabul yang dimaksudkan pada pasal 285 hingga pasal 296 tersebut keseluruhannya mengarah pada perbuatan kekerasan seksual yang bersifat fisik, baik dengan ancaman kekerasan (perkosaan) maupun bujuk rayu. Tidak ada dalam pasal-pasal tersebut yang mengatur tentang perbuatan kekerasan seksual yang bersifat verbal.

Kekerasan seksual di ruang publik, didominasi oleh kekerasan yang bersifat verbal. Jarang terjadi kekerasan seksual terhadap perempuan di ruang publik yang bersifat fisik. Dengan dominasi kekerasan seksual yang bersifat verbal yang dialami oleh perempuan di ruang publik, menjadikan kekerasan seksual tersebut sulit untuk dikenakan penindakan hukum. Pasal dalam KUHP yang dapat dipergunakan untuk menindak terjadinya kekerasan seksual yang bersifat verbal adalah Pasal 335 ayat 1 butir (1) KUHP tentang perbuatan tidak menyenangkan. Peluang hukum untuk menjerat pelaku pelanggaran kekerasan seksual yang bersifat verbal di ruang publik dengan mempergunakan Pasal 334 ayat 1 butir (1) KUHP ini pupus seiring dengan terbitnya Putusan Mahkamah Konstitusi (MK) No. 1/PUU$\mathrm{XI} / 2013$. Dalam putusannya, MK menganggap bahwa pasal tersebut dihapus karena bertentangan dengan Undang-undang Dasar 1945 (UUD 1945) yang menimbulkan ketidakpastian hukum dan ketidakadilan.

Permasalahan penanganan kasus kekerasan seksual terhadap perempuan di ruang publik tidak hanya berhenti pada hukum materiil, namun juga terjadi pada hukum formil. Telah diatur dalam Pasal 184 ayat (1) KUHAP bahwa yang disebut alat bukti yang sah, antara lain keterangan saksi. Sulit untuk melakukan pembuktian terjadinya kekerasan seksual di ruang publik bersifat verbal yang didasarkan pada keterangan saksi. Dengan relasi kuasa yang timpang antara perempuan dan laki-laki, menjadikan sebagian besar masyarakat menganggap perbuatan kekerasan seksual bersifat verbal terhadap perempuan dianggap sebagai perbuatan yang lumrah dan tidak mempedulikannya. Dengan kondisi ini, walaupuan perbuatan kekerasan seksual dilakukan dihadapan orang banyak, namun sulit untuk diperoleh saksi. Hal ini karena orang lain selain korban, beranggapan perbuatan pelaku bukan sebagai kekerasan seksual.

\section{SIMPULAN}

Angka kejadian kekerasan seksual terhadap perempuan di ruang publik yang dilaporkan dan tercatat di Komnas Perempuan adalah angka tidak bersifat faktual. Fakta angka kekerasan seksual di ruang publik lebih besar daripada kekerasan seksual yang terlaporkan. Kekerasan seksual terhadap perempuan merupakan kekerasan simbolik yang ingin menunjukkan dominasi dan kuasa laki-laki terhadap perempuan. Perempuan tidak memiliki otonomi terhadap tubuhnya. Tubuh perempuan bukan lagi milik perempuan, namun milik laki-laki. Tubuh perempuan didefinisikan dan dikonstruksikan oleh pemikiran laki-laki. Dengan konstruksi sosial, perempuan menjadi liyan dari dirinya sendiri. Diperlukan edukasi sejak dini, untuk melakukan dekonstruksi sosial dengan menempatkan relasi yang setara antara laki-laki.

Untuk melindungi perempuan, maka diperlukan pembaharuan hukum. Saat ini hukum materiil di Indonesia masih belum mampu menjangkau terjadinya kekerasan seksual di ruang publik. Pengaturan dalam KUH Pidana masih banyak menjangkau kekerasan seksual yang bersifat fisik. Sedangkan UU Kekerasan Dalam Rumah Tangga, hanya menjangkau kekerasan seksual yang dilakukan di ranah domestik/privat.

Pembaharuan hukum juga perlu dilakukan pada hukum formil. Pengaturan dalam hukum formil masih belum mampu menjangkau terjadinya kekerasan seksual di ruang publik. Hukum formil masih membutuhkan adanya alat bukti berupa keterangan saksi. Kekerasan seksual terhadap perempuan di ruang publik biasa dilakukan melalui kalimat (verbal) atau tindakan yang dianggap biasa oleh sebagian besar warga. Kondisi ini menyulitkan perempuan untuk melaporkan kejadian kekerasan seksual yang dialaminya, karena tidak adanya saksi. Hukum di Indonesia juga belum memberikan pemulihan kondisi perempuan yang menjadi korban kekerasan seksual. Diperlukan adanya sanksi hukum bagi pelaku kekerasan yang bersifat restitutif dengan melakukan pemulihan kondisi perempuan sebagai korban kekerasan seksual.

\section{DAFTAR PUSTAKA}

Arivia, A. G. (2016, Mei). Kekerasan Seksual dan Simbolis: Studi Kasus di Jakarta. Jurnal Perempuan, 21 No. 2, 201 - 210.

Arivia, G. (2003). Filsafat Beperspektif Feminin. Jakarta: Yayasan Jurnal Perempuan.

B. Herry Priyono, S. (2010). Menyelamatkan Ruang Publik. In F. B. Hardiman, Ruang Publik. Melacak "Partisipasi Demokratis" dari Polis sampai Cyberspace (p. 372). Yogyakarta: Kanisius.

Beauvoir, S. d. (1989). Second Sex. New York: Women Life Today Vintage.

Bourdieu, P. (1995). Language and Symbolic Power. (G. R. Adamson, Trans.) Cambrige: Polity Press. 
Foucault, M. (1980). Surveiller et Punier - Dicipline and Punish, the birth of prison). (A. Sheridan, Trans.) New York: Vintage Books, a Division of Random House, Inc.

Foucault, M. (2008). La Volonte de Savoir (Historie de Sexualite). Ingin Tahu Sejarah Seksualitas. (J. Couteau, Ed., \& R. S. Hidayat, Trans.) Jakarta: Yayasan Obor Indonesia.

Hardiman, F. B. (2010). In F. B. Hardiman, Ruang Publik. Melacak "Partisipasi Demokratis" dari Polis sampai Cyberspace (p. 2). Yogyakarta: Kanisius.

Karya Widyawati, A. E. (2011, September). Peranan Ruang Terbuka Publik Terhadap Tingkat Solidaritas dan Kepedulian Penghuni Kawasan Perumahan di Jakarta. Jurnal Ilmiah Factor Exacta, Vol. 4 No. 3, 248.

Komnas Perempuan. (2009). 15 Bentuk Kekerasan Seksual, Sebuah Pengenalan. Jakarta.

Komnas Perempuan. (2018). Catatan Tahunan Komnas Perempuan. Jakarta.

Levi, M. (1994). Violent Crime. In the Oxford Handbook of Criminology. (R. M. Mike Maguire, Ed.) Oxford: Clarendon Press.

Neil Alan Weiner, M. A. (1990). Violence: Patterns, Causes, Public Policy. New York: Harcourt Brace Jovanovich.

Wibowo, A. S. (2010). Kepublikan dan Keprivatan di Dalam Polis Yunani Kuno. In F. B. Hardiman, Ruang Publik, Melacak Partisipasi Demokratis Dari Polis Sampai Cyberspace (pp. 23 - 24). Yogyakarta: Kanisius.

World Health Organization (WHO). (2016). Sexual Violence - World Report on Violence and Healt. New York. 